\title{
Statistics as a basis for discrimination in the insurance business
}

\author{
Margarida Lima Rego*
}

\begin{abstract}
The European Court of Justice has held that as from 21 December 2012 insurers may no longer charge men and women differently on the basis of scientific evidence that is statistically linked to their sex, effectively prohibiting the use of sex as a factor in the calculation of premiums and benefits for the purposes of insurance and related financial services throughout the European Union.

This ruling marks a sharp turn away from the traditional view that insurers should be allowed to apply just about any risk assessment criterion, so long as it is sustained by the findings of actuarial science. The naïveté behind the assumption that insurers' recourse to statistical data and probabilistic analysis, given their scientific nature, would suffice to keep them out of harm's way was exposed. In this article I look at the flaws of this assumption and question whether this judicial decision, whilst constituting a most welcome landmark in the pursuit of equality between men and women, has nonetheless gone too far by saying too little on the million dollar question of what separates admissible criteria of differentiation from inadmissible forms of discrimination.
\end{abstract}

Keywords: statistics, insurance, sex discrimination, inequality, Test-Achats.

\section{Introduction}

It is given that differentiation based on stereotyping or on unsupported prejudice amounts to discrimination and should therefore be prohibited. But what about differentiation based on accurate statistical findings? This is the type of differentiation most commonly used in 
the insurance business, where, for instance, a large number of empirical studies have demonstrated that, from a statistical point of view, women have a higher life expectancy than men, that women are more frequent users of healthcare services than men, or that serious traffic accidents are more often caused by men than by women. ${ }^{1}$

The European Court of Justice ('ECJ') has held that as from 21 December 2012 insurers may no longer charge men and women differently on the basis of scientific evidence that is statistically linked to their sex, effectively prohibiting the use of sex as a factor in the calculation of premiums and benefits for the purposes of insurance and related financial services throughout the European Union. ${ }^{2}$

This ruling marks a sharp turn away from the traditional view that insurers should be allowed to apply just about any risk assessment criterion, so long as it is sustained by the

\footnotetext{
* Margarida Lima Rego, MJur/MPhil (Oxon), PhD (UNL). Professor of Private Law at Nova Law School, Universidade Nova de Lisboa, 1099-032 Lisbon, Portugal. Researcher, CEDIS. An earlier version of this article was presented at the Rights and Inequalities: Paradoxes and Alternatives conference held on 12 November 2013 at ICS (U. Lisboa). I am grateful to Sofia Aboim for having made it happen and to conference participants and anonymous reviewers for their helpful comments. The usual disclaimer applies.
}

1 See Eurostat's databases on life expectancy at birth by sex at <http://epp.eurostat.ec.europa.eu/portal/page/portal/eurostat/home/> (last visited 28 August 2014). See also pp. 6 ff of the European Commission's Explanatory Memorandum, COM(2003)657, of 05.11.2003, on the proposal of what would become the EU Gender Directive, and CIVIC CONSULTING's Study on the use of age, disability, sex, religion or belief, race or ethnic origin and sexual orientation in financial services, in particular in the insurance and banking sectors (2010), commissioned by the European Commission, full text available at <http://www.civic-consulting.de/project_42.html> (last visited 28 August 2014).

${ }^{2}$ Case C-236/09, Association des Consommateurs Test-Achats ABSL, Yann van Vugt, Charles Basseler v. Conseil des Ministres, [2011] ECR I-00773, known simply as Test-Achats, on the invalidity of Art. 5(2) of the EU Gender Directive. 
findings of actuarial science. The naïveté behind the assumption that insurers' recourse to statistical data and probabilistic analysis, given their scientific nature, would suffice to keep them out of harm's way was exposed. In this article I look at the flaws of this assumption and question whether this judicial decision, whilst constituting a most welcome landmark in the pursuit of equality between men and women, has nonetheless gone too far by saying too little on the million-dollar question of what separates admissible criteria of differentiation from inadmissible forms of discrimination.

No argument is made in this article against the ECJ's ruling that sex should not be used as a risk assessment criterion in the insurance business. Whilst this article will focus on sex, some of my conclusions also apply to the use of statistical findings as justification of a differentiation based other suspect classifications set forth in Article 21(1) of the Charter of Fundamental Rights of the European Union (the 'Charter').

I argue that sex should not be used as a risk assessment criterion because in some if not all instances where sex has been used as such in the insurance business it cannot be shown that statistical differences related to sex are unrelated to past forms of discrimination, and because a person's sex has not been shown to be the only or even a deciding factor for outcomes relevant to insurance, but is rather used as a convenient surrogate criterion for other, more determining features.

I argue, more generally, that a twofold test consisting of the following questions should be used so as to separate admissible criteria of differentiation from inadmissible forms of discrimination: 1 . Is there evidence in support of the conclusion that the statistical findings under consideration have an explanation that is unrelated to some form of past discrimination? This question should be answered affirmatively in order for the differentiation to pass this part of the test. 2. Comparing the actuarial factor under scrutiny 
with every other possible factor, is there evidence to support the conclusion that that there is no other known factor which (i) would have been more suitable as a predictor of the relevant outcome or (ii) which would have been equally or even slightly less suitable for that purpose but which would have been less burdensome from a human rights perspective? This question should also be answered affirmatively in order for the differentiation to pass this part of the test.

The article is divided into eight sections, including this introduction (1) and the conclusions (8). Section 2 sets out the legal provisions which form the background to the ensuing discussion. Section 3 contextualizes a person's sex as one of a series of suspect classifications and briefly presents the notion of rational discrimination so as to characterize the type of discrimination most commonly used in the insurance business. Section 4 outlines the reasons behind the popularity of sex as a risk assessment criterion in the insurance business. Section 5 draws on a couple of landmark decisions of the United States Supreme Court taken in the different but related context of racial discrimination in America in order to illustrate why it is vital that a stricter test than the rational standard be applied to any attempt to differentiate on the basis of a suspect classification so as to separate admissible criteria of differentiation from inadmissible forms of discrimination. Section 6 lays down the above mentioned twofold test aimed at separating admissible criteria of differentiation from inadmissible forms of discrimination based on statistical findings. Section 7 points out that, even though the use of sex as an actuarial factor has failed that test, a different outcome might well lie ahead if, also in the context of insurance, the test were to be applied to another suspect classification, such as a person's age. 


\section{Background}

Article 5(1) of Council Directive 2004/113/EC of 13 December 2004 implementing the principle of equal treatment between men and women in the access to and supply of goods and services, better known as the 'EU Gender Directive', proclaimed a general ban on the use of sex as an actuarial factor in the calculation of premiums and benefits for the purposes of insurance and related financial services. However, the impact of this unisex rule on the insurance business was deflated, to a great extent, by the derogation contained in Article 5(2), which permitted the application of proportionate differences in individuals' premiums and benefits "where the use of sex is a determining factor in the assessment of risk based on relevant and accurate actuarial and statistical data' ${ }^{3}$

This derogation was exclusive of costs related to pregnancy and maternity, on the ground, it would appear, that the economic burden of human reproduction should not be allowed to rest on women's shoulders alone. ${ }^{4}$ In this case the implementation of measures aimed at complying with the unisex rule at national level could at best be deferred by Member States for a period of up to two years as from 21 December 2007, the date of entry into force of the EU Gender Directive. The derogation contained in Article 5(2) was more generous to every other sex based differentiation, merely determining that Member States which had chosen to rely on the derogation - and all Member States did make use of this opt-out provision - were to review their decision by 21 December 2012.

\footnotetext{
${ }^{3}$ Recitals 18 and 19 of the EU Gender Directive are also relevant to this discussion. See also the European Commission's Explanatory Memorandum (cited supra n. 1). On the complex negotiations over the wording of the insurance-related aspects of the EU Gender Directive, see E. C. di TORELLA, "No sex please: we're insurers", (2013) 38 E. L. Rev, 638-654.

${ }^{4}$ Article 5(3) and Recital 20 of the EU Gender Directive.
} 
The ECJ did not wait for such a decision to be made by Member States: on 1 March 2011, in what would be known as the Test-Achats ruling, the Court declared that this derogation would cease to be effective on 21 December $2012 .^{5}$ I believe this is the first time such a universal ban on the use of sex as actuarial factor has been put in place. ${ }^{6}$ In USA, where much debating on the (un)fairness of so-called gender rating took place in the literature of the 1970s and $1980 \mathrm{~s}^{7}$ over a couple of important judgments of the Supreme Court, no such general ban on sex discrimination is yet to be found. ${ }^{8}$ In USA, as in Canada, a distinction should be drawn between sex-based differentiations made by employers, including those applicable to occupational pension schemes, which have largely been banned, and those made by insurers, which have not met with a similar fate except in a relatively small number of states and only with regard to specific lines of insurance. ${ }^{9}$ However, a sign that this

5 Test-Achats (cited supra n. 2). The Court appealed to the notion of invalidity, stating that "Article 5(2) of Directive 2004/113 is invalid with effect from 21 December 2012”'.

${ }^{6}$ See J. SASS and F. T. SEIFRIED, "Insurance markets and unisex tariffs: is the European Court of Justice improving or destroying welfare?”, (2014) Scandinavian Actuarial Journal 228-254, at 228-229.

${ }^{7}$ See S. L. Kimbald, "Reverse sex discrimination: Manhart”, (1979) 4 American Bar Foundation Research Journal 83-139; K. S. ABRAHAM, "Efficiency and fairness in insurance risk classification", (1986) 71 Virginia Law Review 403-451; L. WORTHAM, "Insurance classification: too important to be left to the actuaries" (1986) 19 University of Michigan Journal of Law Reform 349-423; or J. GAULDING, "Race sex and genetic discrimination in insurance: what's fair", (1995) 80 Cornell Law Review 1646-1694.

8 The judgments were City of Los Angeles Dept. of Water \& Power v. Manhart, 435 U.S. 702 (1978) ('Manhart') and Arizona Governing Committee for Tax Deferred Annuity and Deferred Compensation Plans, etc., et al. v. Norris, etc., 103 S. Ct. 3492 (1983) ('Norris'). Both concerned sex discrimination in occupational pension schemes and discussed it in the context of Title VII of the Civil Rights Act of 1964.

9 This subject matter has traditionally been dealt with at state level. See E. SHILTON, "Insuring inequality: sexbased mortality tables and women's retirement income", (2011-2012) 37 Queen's Law Journal 383-435, at 404409 and $417-423$. 
might be about to change can be found in $\ 1557$ of the Patient Protection and Affordable Care Act ('Obamacare'), whereby as from 1 January 2014 insurers may no longer charge individuals and small employers different health insurance premiums on the basis of gender. ${ }^{10}$

In order to assist Member States with the implementation of the Test-Achats ruling at national level, the European Commission issued a Communication on 22 December 2011. ${ }^{11}$ In this Communication, the European Commission recognized that this ruling would have implications in all Member States, given that all Member States still allowed gender differentiation for at least one type of insurance: life insurance. ${ }^{12}$ On 6 February 2014, EIOPA - the European Insurance and Occupational Pensions Authority - issued a Report on the implementation of the Test-Achats ruling into national legislation, according to which in December 2013 it had already been implemented in 25 out of the current 28 Member States. ${ }^{13}$

10 See the report by the NATIONAL WOMEN'S LAW CENTER, Turning to fairness. Insurance discrimination against women today and the Affordable Care Act, March 2012, available at: <http://www.nwlc.org/sites/default/files/pdfs/nwlc_2012_turningtofairness_report.pdf> (last visited 28 August 2014). Test-Achats itself is also bound to have an impact in other jurisdictions. On its likely impact in South Africa, see B. KuSCHKE, "Gender equality in insurance”, (2012) 3 De Jure 624-630.

11 The full text of the European Commission's guidelines on the application of Council Directive $2004 / 113 / \mathrm{EC}$ to insurance in light of the Test-Achats ruling is available at: <http://ec.europa.eu/justice/gender-equality/files/com_2011_9497_en.pdf> (last visited 28 August 2014). 12 At p. 2.

13 The full text of the EIOPA Report is available at: <https://eiopa.europa.eu/fileadmin/tx_dam/files/publications/reports/8.2._EIOPA-CCPFI-13091_Test_Achats_rev2.pdf> (last visited 28 August 2014). According to this Report, in the three Member States where the Test-Achats ruling had not yet been implemented there was legislation to that effect in the 


\section{Sex as a suspect classification}

All persons should be treated as equals. This means that, as individuals, each of us should be treated with an equal measure of concern and respect. ${ }^{14}$ It does not mean that we should all be given the same treatment in spite of our differences. Treating persons as equals may call for unequal treatment when their starting point is different. The principle of equality should not be regarded as a ban on differentiation - on the recognition of individual differences; nor, for that matter, should it be seen as a ban on generalization - on the disregard for individual differences. There is no rule-making without generalization. In fact, there is no thought without it: to think is to forget a difference, to generalize, to abstract. ${ }^{15}$

Even my initial statement, that all persons should be treated as equals, calls for at least one differentiation: that which separates those classified as a person from all other beings. And one generalization: that which puts us all into the same class, as human beings. The question then becomes: What separates admissible criteria of differentiation from inadmissible forms of discrimination? $?^{16-17}$

process of being adopted. Such Member States were Italy, Luxembourg and Portugal.

${ }^{14}$ A notion which can be traced back to R. DwORKIN in Taking rights seriously, Harvard University Press, 1977, p. 370 .

15 As very aptly phrased by J. L. BORGES in Funes the Memorious (1942).

16 See L. AlEXANDER, "What makes wrongful discrimination wrong? Biases, preferences, stereotypes, and proxies", (1992) 141 University of Pennsylvania Law Review, 149-219. As this author points out, 'answering this question is much more difficult than most people assume'. The question 'has seldom been addressed, much less answered' (p. 151).

17 The concept of discrimination is also not beyond dispute. See A. Altman, "Discrimination", The Stanford Encyclopedia of Philosophy (Spring 2011 Edition), Edward N. Zalta (ed.), URL = 
There is no simple all-embracing answer to this question. American jurisprudence has developed the notion of suspect classifications. These classifications are those which have been identified as being most likely to lead to discrimination, because historically they have been major sources of discrimination. Constitutional laws often include lists of such suspect classifications. One such list may be found in Article 21(1) of the Charter: ${ }^{18}$

'Any discrimination based on any ground such as sex, race, colour, ethnic or social origin, genetic features, language, religion or belief, political or any other opinion, <http://plato.stanford.edu/archives/spr2011/entries/discrimination/>. Definitions of both direct and indirect discrimination are included in Art. (a) and (b), respectively, of the EU Gender Directive. This article is concerned with direct forms of discrimination: in the situations under consideration sex is directly and overtly used as an actuarial factor in the insurance business. On the use of statistics in the context of indirect discrimination, see infra n. 20. The Directive's reference to less favourable treatment might lead one to suppose that only those instances where women would be charged a higher premium than men might be classified as discriminatory, but any difference in treatment may be so classified. More enlightening is the definition contained in Art. 1 of the United Nations Convention on the Elimination of All Forms of Discrimination Against Women, of 18 December 1979, which condemns 'any distinction, exclusion or restriction made on the basis of sex which has the effect or purpose of impairing or nullifying the recognition, enjoyment or exercise by women, irrespective of their marital status, on a basis of equality of men and women, of human rights and fundamental freedom in the political, economic, social, cultural, civil or any other field'.

${ }^{18}$ Following the entry into force of the Lisbon Treaty on 1 December 2009, this Charter has the same legal force as the treaties of the European Union. On the evolution and current status of the Charter, see S. IGLESIAS SÁNCHEZ. "The Court and the Charter: the impact of the entry into force of the Lisbon Treaty on the ECJ's approach to fundamental rights", 49 CML Rev. (2012), 1565-1612. The author highlights 'the role of the Charter as the primary source of fundamental rights in the EU legal order' (p. 1599). On the coexistence between the Charter and national frameworks of fundamental rights protection in Europe, see D. SARMIENTO, "Who's afraid of the Charter? The Court of Justice, national courts and the new framework of fundamental rights protection in Europe”, 50 CML Rev. (2013), 1267-1304. 
membership of a national minority, property, birth, disability, age or sexual orientation shall be prohibited. ${ }^{, 19}$

Surely differentiation based on stereotyping or on unsupported prejudice amounts to discrimination and should therefore be prohibited. But what about so-called rational discrimination ${ }^{20}$ In this article $\mathrm{I}$ take issue with one particular form of such rational discrimination: that of differentiation based on accurate statistical findings, which is the type of differentiation most commonly resorted to in the insurance business, an insurer's differentiations being characteristically rational, not only in the sense that such differentiations are based on scientifically proven risk assessment methods applying probabilistic theory to statistical data, but also in a strictly utilitarian sense, given that the criteria applied in reaching such differentiations are those that allow the insurer to reach its goal of correctly measuring and pricing the risks they take at the lowest possible cost. ${ }^{21}$

\section{Sex as an actuarial factor in the insurance business}

Insurance is a risk management tool aimed at reducing the negative impact of an uncertain future event by securing the financial means required to face it. When faced with such a

\footnotetext{
${ }_{19}$ Also relevant to this article's subject matter is Art. 23 of the Charter (equality between men and women). Although the Charter only acquired its present binding force in 2009, Recital 4 of the EU Gender Directive expressly refers to Arts. 21 and 23 of the Charter. See A. PERIPOLI, "Is the ECJ finally putting the Charter to work?”, (2012) 128 Law Quarterly Review, 212-216, at 214.

20 The expression 'rational discrimination' was coined by D. A. STRAuSs, "The myth of colorblindness", (1986) The Supreme Court Review 99-134. Se also M. J. KATZ, "Insurance and the limits of rational discrimination”, (1990) 8 Yale Law \& Policy Review, 436-458.

21 This is why the derogation contained in Art. 5(2) almost entirely deflated the principle of Art. 5(1) of the EU Gender Directive.
} 
risk, we may deal with it ourselves, for instance by taking steps to eliminate it, or to reduce the probability or severity of the potential loss or even by choosing to retain this risk, budgeting the means with which to face such potential loss. Alternatively we may transfer this risk to an insurer in exchange for a fee, thereby choosing a certain, smaller loss - the payment of a premium - over an uncertain, potentially much larger loss.

At the root of the insurance business is the law of large numbers, which is a principle of probability theory according to which, the larger the number of analogous exposure units independently exposed to loss, the closer the actual loss will be to the value of the expected loss. ${ }^{22}$ In a nutshell: no one can predict if and when they will be involved in a car accident but, thanks to the law of large numbers, it is possible to estimate the number of car accidents that will occur in Lisbon in 2014 with a relatively small margin of error.

We, risk-averse individuals, are happy to choose a certain, smaller loss over an uncertain, potentially much larger loss. Insurers, on the other hand, have no reason to be averse to take up our risks, because their pool of clients is large enough for them to be able to measure such risks. They will not be able to predict which of their clients will suffer a loss but they should be capable of estimating, with an acceptable margin of error, how high their aggregate loss will be, and may thus budget accordingly.

Actuarial science is the discipline of applied mathematics concerned with risk assessment in the insurance business. Actuaries draw on statistical analysis in order to measure each

\footnotetext{
${ }^{22}$ See, for instance, C. AITKEN/ P. ROBERTS/ G. JACKSON, Fundamentals of probability and statistical evidence in criminal proceedings, Royal Statistical Society, 2010, full text available at: <http://www.maths.ed.ac.uk/ cgga/rss.pdf> (last visited 28 August 2014), at 102.
} 
individual risk and price it accordingly. They draw on their hard data so as to come up with different outcome probabilities for men and women. ${ }^{23}$

If insurer were to charge all policyholders the same premium, regardless of the characteristics of each individual risk, on an individual level the policyholders seeking to cover better-than-average risks would subsidize those which with worse-than-average risks. This was indeed how life insurance was sold in the 19th century. It did not work out very well for insurers: it has been argued that the existence of competition amongst insurers in the marketplace and the phenomenon known as adverse selection generally prevents this from successfully taking place, because such a scheme would only be attractive to the latter group of policyholders, the former being better served by an insurer which would differentiate between good and bad risks. ${ }^{24}$ By definition, insurance is discriminating: its modus operandi is to classify risk-bearers into more or less homogeneous groups and price their insurance according to such classifications, so that each group member will pay the premium that best matches its individual risk.

The two risk assessment or actuarial factors most widely used in the field of personal insurance are a person's age and biological sex $x^{25}$.

\footnotetext{
23 See supra n. 1.

${ }^{24}$ See J. GAUlding, op. cit. supra n. 7, at pp. 1651-1652; and, criticizing this view, T. BAKER, "Containing the promise of insurance: adverse selection and risk classification", (2002-2003) 9 Connecticut Insurance Law Journal 371-396 (Part I). The author argues that 'much of the literature on insurance treats risk classification as an inevitable, essential response to the problem of adverse selection and ignores the role of risk classification in promoting adverse selection' (p. 276).

${ }^{25}$ It is often unstated whether the determining factor is a person's biological sex or rather their gender, but it is my understanding that statistical data used by insurers is based on biological sex, not gender. According to
} 
The main reason, if sometimes not the only reason, behind the choice of a person's age and sex is their comparative availability, simplicity and reliability. Insurers are really not that interested in our age and sex per se: their interest in these factors is purely instrumental. If we walked around with a chronometer on our foreheads indicating our remaining time on earth, there would be no need for insurers to worry about surrogate factors such as our age or sex when it came to the pricing of life insurance. ${ }^{26}$

Since the information that they would really wish to obtain is either unavailable or only available at too high a cost for their activity to be lucrative, they have to rely on statistics. They single out certain factors because a statistical correlation, albeit an imperfect one, has been found between these factors and those that insurers really care about - say, our

the World Health Organization's definitions, ' 'sex' refers to the biological and physiological characteristics that define men and women', whereas ' 'gender' refers to the socially constructed roles, behaviours, activities, and attributes that a given society considers appropriate for men and women', available at: <http://www.who.int/gender/whatisgender/en/> (last visited 28 August 2014). On the subject of the risk assessment factors most widely used in the insurance business, see CIVIC CONSULTING's Study (cited supra n. 1).

26 As stated above in n. 12, this article is concerned with direct forms of discrimination. However, oftentimes recourse to a suspect classification will not be as apparent, surrogate factors being used as proxies. This practice has been detected in a large number of equal employment cases. In such cases statistics may be used as evidence that indirect discrimination is taking place. On this, see J. L. GASTWIRTH, "Methods for assessing the sensitivity of statistical comparisons used in Title VII cases to omitted variables", (1992) 33 Jurimetrics Journal 19-34. A different distinction is that submitted by D. HELlman, "Two types of discrimination: the familiar and the forgotten" (1998) 86 California Law Review 315-361, between proxy discrimination, which 'uses the classification in the law as a means to reach a set of persons with a different, correlated trait', and non-proxy discrimination, which 'aims at the set defined by the classification itself (p. 315). In this sense, this use of statistics falls under the category of proxy discrimination, given that actuarial factors are used as surrogate factors for what insurers are ultimately aiming for. 
longevity. Those factors are chosen, and not others, because information on the past is readily available, such information can be obtained quite simply by asking potential insured persons to tick a box or to fill in a number, and their answers are also easily verifiable by insurers. In sum, although insurers' interest in knowing these factors is merely instrumental, these factors have been so widely resorted to because they are cost-effective: using them makes sense from a financial perspective. ${ }^{27}$

And yet both factors - a person's age and sex - are suspect classifications. The terseness of the reasoning in the Test-Achats judgment might lead one to wander whether a similar fate awaits the use by insurers, as actuarial factors, of age or every other suspect classification. If this were to happen, of course personal insurance as we know it would cease to be a viable business. In the next sections I argue that only by taking into consideration the undeclared reasons which justify the ECJ's decision in Test-Achats may we grasp the distinguishing features that enable us to separate admissible from inadmissible uses of suspect classifications as actuarial factors.

\section{Why sex should not be used as an actuarial factor? a lesson from USA}

Let us assume that the statistical findings under consideration are accurate, i.e. that they correctly describe a positive or negative correlation between a person's sex and the likelihood of a given outcome. Is that all we should ask of such conclusions? For a long time this question was answered in the affirmative. Insurers were not basing their decisions to apply different premiums to men and women on prejudice. Their decisions were based

\footnotetext{
${ }^{27}$ See S. MAITZEN, "The ethics of statistical discrimination", (1991) 17 Social Theory and Practice, 23-45; and Civic Consulting's Study, cited supra n. 1, at 6, 9, 33-34, 43, 48, 53-54, 59, 72 and 77.
} 
on scientifically proven risk assessment methods applying probabilistic theory to statistical data. ${ }^{28}$ How could this be wrong?

The answer to this question can be found in the American doctrine of suspect classifications. According to this doctrine, closer scrutiny should be carried out on any attempt to differentiate on the basis of these suspect classifications than on other types of differentiation, given the presumption of wrongness that hovers above them. Hence, whilst other types of differentiation might undergo a more lenient test that may be satisfied on the ground that this differentiation is a rational way of furthering a legitimate governmental purpose, when suspect classifications are at stake rationality is a necessary but not a sufficient condition for their use to be deemed non-discriminatory. Such use will be barred unless the so-called strict scrutiny test is satisfied: the differentiation must be justified by a compelling governmental interest, it must be narrowly tailored so as to satisfy that interest and it must be the least restrictive means available for pursuing that interest. ${ }^{29}$ In other words, when it comes to differentiation based on suspect classifications, even rational discrimination will be struck down as wrong unless the stricter test is satisfied.

By recognizing that insurers' decisions to differentiate on the ground of a person's sex, or of any other suspect classification, are based on scientifically proven risk assessment methods applying probabilistic theory to statistical data, all we are saying is that they are

\footnotetext{
28 See, for instance, P. WATSON, "Equality, fundamental rights and the limits of legislative discretion: comment on Test-Achats', (2011) 36 EL Rev., 896-904. The author asks: 'If, for example, it can be proved that persons of a particular race or ethnic origin are unlikely to be exposed to a particular risk or stand a lesser chance of being so than others in the insured group, why should this not be reflected in the insurance premium they pay for coverage of that risk?' (at 904).

${ }^{29}$ See, for instance, A. WINKLER, «Fatal in theory and strict in fact: an empirical analysis of strict scrutiny in the Federal Courts» (2006) 56 Vanderbilt Law Rev 793-871, at 798-801.
} 
rational. The application of a stricter test should follow. However, the scientific basis of the actuaries' work has widely been put forward as ground for some sort of waiver of a stricter or indeed of any further testing.

In order to illustrate why it is vital that a stricter test than the rational standard be applied to differentiations based on suspect classifications, even in the field of insurance, I shall go back in time, to a couple of decisions of the United States Supreme Court taken in the different but related context of racial discrimination in America.

\section{Brown v. Board of Education ${ }^{30}$}

This was a landmark judgment of the United States Supreme Court, according to which state laws establishing racial segregation in the public educational system were unconstitutional. In this class action, the claimants, parents of about 20 black children attending elementary schools in Kansas, argued that racial segregation allegedly providing separate but equal treatment of both white and black Americans instead perpetuated an inferior treatment of black Americans. The Supreme Court unanimously held that even if segregated black and white schools were proven to be of equal quality in all respects, segregation itself was psychologically harmful to black Americans. Quoting this decision: 'We conclude that, in the field of public education, the doctrine of 'separate but equal' has no place. Separate educational facilities are inherently unequal.’

Providing this ground-breaking decision with its theoretical foundations was a comparatively straightforward mission to accomplish. By the time it was reached, the scientific community had made it clear enough that segregation was unsupported by 30347 U,.S. 483 (1954). This has been called "the Supreme Court's greatest anti-discrimination decision". D. A. STRAuSs, "Intent and the taming of Brown", (1989) 56 Cbicago Law Review, 935-1015, at 937. 
scientific evidence, ${ }^{31}$ so this time the issue under appreciation was not brought to the attention of the Supreme Court.

\section{Palmore v. Sidoti ${ }^{32}$}

In this case, the United States Supreme Court unanimously overturned a decision by a Florida state court which changed a previous child custody judgment based on a change of circumstances after a white child's white mother, who had been awarded custody of her child, remarried a black man. The child's white father was awarded custody of their child. Both parents were found to be equally fit for parenthood. The court found that it was in the best interests of the child to be raised by her father because, all other factors being equal, this child would most probably be the victim of social stigmatization if brought up by an interracial couple, an issue which would not arise if she were to be raised by her white father.

In this case the Supreme Court did not question the state judge's factual conclusion that the child would most probably be the victim of social stigmatization if brought up by an interracial couple. Indeed, it explicitly accepted this conclusion.

'The question (...) is whether the reality of private biases and the possible injury they might inflict are permissible considerations for removal of an infant child from the custody of its natural mother. We have little difficulty in concluding that they are

\footnotetext{
${ }^{31}$ See, most notably, The Race Question, a 1950 UNESCO statement on the subject of race, full text available at: < http://unesdoc.unesco.org/images/0012/001282/128291eo.pdf> (last visited 28 August 2014).

32466 U.S. 429 (1984).
} 
not. The Constitution cannot control such prejudices but neither can it tolerate them? ${ }^{33}$

Going back to Brown: putting an end to segregation often caused some black and white children to suffer psychological harm. There were social disturbances of all sorts in a variety of communities. In some of them education was even interrupted for a while. But the harm caused to these children, black and white, was never found by the Supreme Court as a worthy basis for delay of the desegregation process. ${ }^{34}$ The principle upheld in Brown required the Supreme Court to reverse the decision in Palmore. In determining which decision would be in the best interests of the child, the court could not take into consideration the undisputed fact that a large part of this child's community was racially prejudiced and would therefore most probably subject this child to social stigmatization. To take that fact into consideration would be intolerable from a constitutional point of view. ${ }^{35}$

In sum, the question whether or not the state judge's factual conclusion was accurate did not bring the discussion in Palmore to an end. The state judge's factual conclusion might have been accurate, and yet it was found to be unusable by the United States Supreme

33 At 433-434 (italics added). D. A. STRAUSS, op. cit. supra n. 20, after analysing these and other judgments of the U.S. Supreme Court, concludes that it is a fundamental principle of the law of the Equal Protection Clause of the U.S. Constitution that judges be race-conscious, not colour-blind.

34 See, for instance, Watson v. City of Memphis, 373 U.S. 526 (1963).

35 Subsequently the same reasoning was applied by the US Supreme Court to instances of rational discrimination of women in the workplace. See, for instance, Manhart (cited supra n. 8). In this case the Department required female employees to make larger contributions to its pension fund than their male colleagues, basing this requirement on the undisputed fact that, from a statistical perspective, women have greater longevity than men, and as a consequence the average cost of a female retiree's pension was greater than that of the average make retiree. The Supreme Court held that this requirement violated $\int 703(a)(1)$ of Title VII of the Civil Rights Act of 1964. 
Court. By the same token, whether or not statistical findings are accurate should not be our sole concern. ${ }^{36}$

\section{A twofold test for the separation of admissible criteria of differentiation from inadmissible forms of discrimination}

I take it for granted that the insurance industry plays an important economic and social role and that rules which are meant to facilitate its proper functioning, such as the derogation contained in Article 5(2) of the EU Gender Directive, serve a compelling governmental interest. ${ }^{37}$ However, it is submitted that it is not as narrowly tailored as it should be. In this section I put forward a twofold test aimed at narrowing the rules allowing insurers to differentiate on the basis of a suspect classification.

Statistical analysis, by using past data to predict the future, can be used as an instrument to perpetuate past injustices, in a way that is incompatible with the promotion of equality. ${ }^{38}$ The use of statistical findings, as accurate as they may be, should be similarly deemed intolerable, whenever these findings are based on a suspect classification, if the statistical regularities that are found could be traced back to some form of past discrimination. More rigorously, given the presumption of wrongness, the use of these statistical findings should

\footnotetext{
36 See D. A. STRAuss, op. cit. supra n. 20.

37 The expression is borrowed from the strict scrutiny test as formulated by the US Supreme Court. See above the text in the vicinity of n. 30 .

38 See M. J. KATZ, op. cit. supra n. 20, at 458: 'Although rational discrimination is based on neutral market principles such as profitability and efficiency, its effects are far from neutral. In the insurance market, rational discrimination plays a part in perpetuating- even exacerbating - the economic disparities be-tween the races. This seemingly 'faultless' conduct not only is rooted in the harm of past intentional discrimination, it is a harm in its own right.'.
} 
be barred unless there is evidence in support of the conclusion that these differences and regularities have an explanation that is unrelated to some form of past discrimination.

Other reasons have been invoked by courts and legal authors as grounds for the unfairness of differentiations based on suspect classifications. Amongst such reasons, the one that stands out is the argument that features such as one's race or sex are uncontrollable, in the sense that we do not choose to be born of a given race or sex, as opposed to, say, our acquiring a smoking habit. ${ }^{39}$ Whilst this argument may very pertinent in other contexts, when it comes to suspect classifications such as race or sex I find it somewhat difficult to take in, due to the implication that being born of a given race or sex might be something to avoid, if possible, or that if we were able to choose them this might lead to a somewhat diminished claim to equal treatment. Indeed, it is nowadays largely accepted that race is, to some extent, a trait that we choose to assume as part of our identity. ${ }^{40} \mathrm{I}$ remain unconvinced that something other than the fact that such social groups have historically been major sources of discrimination would justify the application, to any attempt to differentiate on the basis of a suspect classification, of a stricter test than the rational standard that accurate statistical findings so easily pass.

\footnotetext{
39 See, for instance, Y. ThIERY and C. V. SCHOUbroECK, "Fairness and equality in insurance classification", (2006) 31 The Geneva Papers 190-211, at 197-198.

40 See M. JAMES, "Race”, The Stanford Encyclopedia of Philosophy (Winter 2012 Edition), Edward N. Zalta (ed.), $\mathrm{URL}=$ http://plato.stanford.edu/archives/win2012/entries/race/ (last visited 28 August 2014). According to the Unites States Census Bureau, this agency 'collects race data according to U.S. Office of Management and Budget guidelines, and these data are based on self-identification. People may choose to report more than one race group. People of any race may be of any ethnic origin.' Available at
} http://www.census.gov/topics/population/race.html (last visited 28 August 2014). 
I shall not purport to separate the statistical findings that can from those that cannot be traced back to discrimination. This is where legal researchers, judges and other decision makers should step aside and listen to their fellow social scientists. I shall nonetheless try to illustrate the thought process that led me to where I stand.

It would be relatively easy to come up with preposterous examples of how statistical analysis could be used as an instrument to perpetuate past injustices. ${ }^{41} \mathrm{I}$ shall not go into such examples. Let us consider the statistical finding that serious traffic accidents are more often caused by men than by women. Although I am not in a position to evaluate such empirical finding, I would be very surprised if they passed the test: ${ }^{42}$ decades of women being literally driven by men instantly come to mind. ${ }^{43}$ But I do not have the same instant negative reaction to the finding that, on average, women live longer than men. ${ }^{44}$ This

${ }^{41}$ A few examples, mostly related to racial discrimination, are provided by M. J. KATZ, op. cit. supra n. 20. In the 1990s there was public outcry over the news that in the United States a significant number of the country's largest insurers denied health, life and disability coverage to the victims of domestic violence. See D. S. Hellman, "Is actuarially fair insurance pricing actually fair?: a case study in insuring battered women", (1997) 32 Harvard Civil Rights - Civil Liberties Law Review 355-411.

42 This is so regardless of the factual explanation behind these findings. According to P. BUTLER, "'Unused observables' in auto liability insurance: non-use of five claim frequency predictors" (2006), in a paper presented at the Southern Risk and Insurance Association Annual Meeting, Hilton Head, South Carolina (available at http://www.centspermilenow.org/Reprints/771.pdf), there are two competing theories as to why serious traffic accidents are more often caused by men than by women: (i) men are more negligent than women when driving; (ii) on average men drive more miles per year than women do (p. 4).

43 As well as the role commonly attributed to the car as a symbol of masculinity. See, for instance, C. LANDSTRÖM, "A gendered economy of pleasure: representations of cars and humans in motoring magazines", (2006) 19 Science Studies, 31-53.

${ }^{44}$ N. REICH, "The impact of the non-discrimination principle on private autonomy", in The involvement of EU law in private law relationships, D. Leczykiewicz and S. Weatherill (Eds.) (Oxford and Portland OR, 2013), 253- 
undisputed statistical finding might, or it might not be traced back to some form of past discrimination. I expect most sociologists would say that it would be extremely difficult, if not impossible, to find evidence in support of the conclusion that any sex-based differences and regularities are unrelated to some form of past discrimination. Again, discovering whether or not it might is outside the scope of my research. However, if we take a brief look at the literature we will conclude that the reasons for the sex gap in longevity are multifaceted, there being much debate on this topic both from a sociological and from a biological perspective. ${ }^{45}$ To the extent that social factors are found to explain this gap, such factors might well be traced back to discrimination, as happened with the undisputed statistical finding that on average white Americans live longer than black Americans, which formed the basis of different pricing by American insurers until the practice was eventually eradicated in the $1960 \mathrm{~s}^{46}$

277, at 264-269, accepts that a strict proportionality test might have condemned higher tariffs for men in motor insurance and for women in health insurance because of fragmented and inconclusive statistical evidence that did not take into account different risk profiles and lifestyles of insured persons', as in those cases 'sex was a rather 'crude' and therefore discriminatory method of risk determination'. However, the author rejects that the same argument be applied to life insurance, where 'premiums for life insurance should be allowed to be calculated differently for the simple fact that the average life expectancy of women in the EU is longer than that of men'. The author argues that the Court has possibly 'failed to carry out the necessary balancing between 'party autonomy' and 'equal treatment' in the insurance market' (at 268-269).

45 There is no clear scientific evidence of a biological cause for this gap, it being admitted that biological factors could make up only a small percentage of the determinants of this gap. See a summary of the state of the art made by J. E. Seifarth, C. L. MCGowan and K. J. Milne, "Sex and life expectancy" (2012) 9 Gender Medicine 390-401.

${ }^{46}$ See J. GaUlding, op. cit. supra n. 7, at pp. 1659-1660. 
Once again, is that all we should ask of such findings? That they be unrelated to some form of past discrimination? Whilst existing studies have demonstrated that sex is - or has been - treated as a distinguishing feature of outcomes relevant to insurance, they have failed to establish that it is the only or even a determining feature. Hence, in cases where no relation can be found between a given statistical finding and past discrimination a second question should be asked: why has this factor been chosen to the detriment of so many others?

The mere identification of a statistical correlation does not establish cause and effect. Correlations may be strong and it may be tenuous. Even in cases where a strong correlation has been found, correlation never implicates causation - that is to say, the existence of a correlation between fact A and outcome B does not establish that A is the cause of B. A strong correlation can be found whenever the chosen factor has triggered the relevant outcome but it is also possible for both to share a common-causal variable, albeit being otherwise unrelated to each other. ${ }^{47}$ Hence, a bias can be found in the selection of an actuarial factor to the detriment of others if the former, albeit correlated to the relevant outcome, bears no significant statistical advantage over the latter.

Now we have come to the well-known contention, originated in the social sciences, that risk assessment is not just about mathematics: that there are elements of subjectivity in every such assessment. ${ }^{48}$ Thanks to the social scientists, there is a growing conscience of

\footnotetext{
47 'For example, shoe size and reading skill are correlated. This does not mean that large feet cause better reading. It simply means that young children do not read as well as adults.' A. V. HILL, The Encyclopedia of Operations Management. A field manual and glossary of operations management terms and concepts (Upper Saddle River NJ, 2011), p. 85.

48 See P. SLOVIC, “Trust, emotion, sex, politics, and science: surveying the risk-assessment battlefield”, (1999) 19-4 Risk Analysis, 689-701. The author sustains the view that the very definition of risk is an exercise in power. (p. 689). See also B. FISCHHOFF, "Risk: a guide to controversy" in Improving risk communication,
} 
the inherent subjectivity in every probabilistic judgment, not in the sense that it is something that might vary from person to person, but in the more ample sense of something that cannot do without interpretation, and as such without human interference and fallibility. ${ }^{49}$

No argument is being made here that the mere establishment of a correlation without proof of causation would always render statistical findings unusable. In order for actuaries to conduct their risk assessments, correlation will suffice. Actuaries need not concern themselves with causation, and that is generally acceptable. But, as I have tried to demonstrate, when it comes to the use of a suspect classification extra care is required.

Sometimes it is admittedly very difficult to establish causation. In cases where the mechanisms of causation are still unknown but there is other evidence to support the conclusion that the chosen factor is indeed the best single predictor of the relevant outcome, then such differentiation could still pass the test. However, given the

Committee on Risk Perception and Communication of the National Research Council (Ed.) (Washington DC, 1989), 211-319; and B. WYNNE, "Institutional mythologies and dual societies in the management of risk" in The risk analysis controversy. An institutional perspective, H. C. Kunreuther and E. U. Ley (Eds.) (Berlin, 1983), 127-143. C. VLEK and P.-J. STALLEN, "Rational and personal aspects of risk", (1980) 45 Acta Psychologica, 273300, had identified six different formal definitions of 'risk'. See also the ROYAL SOCIETY's Risk: analysis, perception and management, F. Warner (Dir.) (London, 1992), at 89-90 and 94-98.

49 A summary of the contribution of the social sciences to this discussion, with references to the most relevant literature, can be found in ROYAL SOCIETY's op. cit. supra n. 48, at 7-8, 89-90, 94-98 and 111-118. On the argument that risk is essentially the product of social construction, see P. SLOVIC, op. cit. supra n. 48, at pp. 689-701, and the abundant literature referenced in nn. 8 to 13 thereof. 'In this view, risk does not exist 'out there', independent of our minds and cultures, waiting to be measured. Instead, human beings have invented the concept risk to help them understand and cope with the dangers and uncertainties of life. Although these dangers are real, there is no such thing as 'real risk' or 'objective risk'." (at 690). 
presumption of wrongness that goes along with differentiations based on a suspect classification, when it comes to these and these alone, it is submitted that mere correlation is not a sufficient ground to form the basis of an admissible differentiation.

In order to pass the second leg of our test we must compare sex with every other possible factor and conclude that no other factor would have been more suitable than sex as a predictor of that outcome and that no other factor would be available, even if slightly less suitable for that purpose from an actuarial perspective, if their use might have been less burdensome from a human rights perspective - as recourse to a given suspect classification must be the least restrictive means available for pursuing the interest in question. ${ }^{50}$ But it is not so.

If our aim were to determine the chance of a person's developing ovarian or prostate cancer, then that person's sex is a key element for this analysis because by knowing whether that person is male or female we would be able to eliminate one or the other. We would not be relying on averages, because every female shares the characteristic of not having a prostate. Hence, even though this characteristic is one that she shares with every other group member, it is still individually hers. If, in contrast, our intention is to determine a person's chances of being involved in a car accident, then our knowledge of that person's sex brings us no actual information on that particular person's driving skills, on her mileage, etc. The European Commission has found that the practice of insurers to use sex as a risk assessment factor in life insurance was also based on ease of use rather than real value as a guide to life expectancy. ${ }^{11}$ Other factors, such as marital status, socio-economic background, employment, regional area, smoking and nutrition habits, were shown to be

\footnotetext{
50 See supra n. 30.

51 See p. 6 of the European Commission's Explanatory Memorandum, cit. supra n. 1, and the Opinion of Advocate General Kokott issued in the Test-Achat case, 30 September 2010, maxime para 67.
} 
more relevant. As seen above, insurers' decision to choose sex is not based on its inherent relevance to their quest, sex being simply used as a surrogate criterion for other more distinguishing but also more elusive human features. ${ }^{52}$

Before the Test-Achats ruling, the ECJ had the opportunity to ponder on similar considerations in the Lindorfer case ${ }^{53}$ in which context guidance was sought in the United States Supreme Court judgment Manhart. ${ }^{54}$

'What is objectionable (and thus prohibited) in such discrimination is the reliance on characteristics extrapolated from the class to the individual, as opposed to the use of characteristics which genuinely distinguish the individual from others and which may justify a difference in treatment. ${ }^{, 55}$

Whilst using this factor would make sense from a purely financial perspective, it is submitted that such financial considerations should not be a decisive argument in this discussion. The existence of more relevant factors, even if less convenient from a financial perspective, leads us to the conclusion that the use of sex as a factor lacks an acceptable justification, amounting to unequal treatment on the ground, not of a person's individual characteristics, but merely of its membership of a historically discriminated social group.

There was much criticism of the Test-Achats ruling for its supposedly harmful impact on insurance premiums, which on average would rise - and apparently have done so - if insurers were unable to differentiate premiums and benefits applicable to men and

\footnotetext{
52 See this article's section 4.

${ }^{53}$ Case C-227/04, Maria-Luise Lindorfer v. Council of the European Union, [2007] ECR I-6767.

${ }^{54}$ Cited supra n. 8.

55 Opinion of Advocate General Jacobs issued in the Lindorfer case, 27 October 2005, para 59.
} 
women. ${ }^{56}$ Nonetheless, just as, in service of a greater good, the black and white children in Brown were expected to suffer some degree of psychological harm in the desegregation process, it is also to be expected that the men and women of our time and age run the risk of paying a little more on average for their insurance. Not surprisingly, change often comes at a cost.

7. Why the same conclusion might not apply to every other suspect classification

What if we leave sex discrimination for a moment and think about age as a factor in risk assessment? If the ECJ had spelt out its reasons for imposing the unisex rule, we might test such reasons against the use of any other actuarial factor, such as a person's age. But this is not what the ECJ has done. The Court did not mention the presumption of wrongness that goes along with differentiations based on a suspect classification, but flatly prohibited the use of sex as a factor in the calculation of premiums and benefits for the purposes of insurance and related financial services, without leaving any room for discussion over the

\footnotetext{
${ }^{56}$ See See J. SASS and F. T. SEIFRIED, op. cit. supra n. 8. The authors conclude that 'mandatory unisex tariffs may result in significant welfare losses' (p. 248). See also E. SCHANZE, "Injustice by generalization: notes on the Test-Achats decision of the European Court of Justice", (2013) 14 GLJ 423-433. The author refers to supporting literature, including a study according to which 'the levelling of gender specific risks led to largely insignificant benefits for the former disadvantaged sex but to partially dramatic rises of the premium of those who were formerly considered better risks' (at 423). See also A. B. VeIga Copo/ A. SÁnChEz Graelis, "Discriminación por Razón de Sexo y Prima del Contrato de Seguro Apuntes Críticos a la Sentencia del Tribunal de Justicia de la Unión Europea (Gran Sala), de 1 de Marzo de 2011, en el Asunto C-236/09 Association Belge Des Consommateurs Test-Achats ASBL Y Otros Contra Conseil Des Ministres”, (2011) 4 Revista de Responsabilidad Civil, 6-33.
} 
possible rebuttal of this presumption. In sum, it has treated a person's sex, not as a suspect classification, but rather as a convict without a trial.

In the case of a person's sex, that might not have been too much of a burden for the insurance industry to bear. But what if the same reasoning is extended to a person's age or to every other classification in Article 21(1) of the Charter?

In the wake of the Test-Achats ruling, the European Commission took pains to make it clear that this ruling only addressed the use of sex in a context where the respective situations of men and women were found comparable by the legislature, not affecting the use of other actuarial factors, such as age and disability, currently not regulated at EU level. The Commission added that the use of such other actuarial factors might not be considered discriminatory, noting that in certain cases the legislator would be complying with the principle of equal treatment of comparable situations by 'recognising that the situations at issue are not comparable and should be treated differently (or that, in spite of comparability, there is an objective justification for treating them differently) ${ }^{57}$

In line with this reasoning, the Commission's proposal for a new equal treatment directive on age and disability recognizes 'the fact that age and disability can be an essential element of the assessment of risk for certain products, and therefore of price. ${ }^{58}$

\footnotetext{
${ }^{57}$ See the European Commission's guidelines, cited supra n. 11, p. 6.

58 The European Commission's Proposal for a Council Directive on implementing the principle of equal treatment between persons irrespective of religion or belief, disability, age or sexual orientation, $\operatorname{COM}(2008) 426$, of 02.07.2008. Recital 15: 'Actuarial and risk factors related to disability and to age are used in the provision of insurance, banking and other financial services. These should not be regarded as constituting discrimination where the factors are shown to be key factors for the assessment of risk.'.
} 
I now recall my earlier acknowledgment that I took it for granted that the insurance industry plays an important economic and social role and that rules which are meant to facilitate its proper functioning serve a compelling governmental interest. From a human rights perspective, just as it is vital that we protect the fundamental right not to be discriminated against, there is growing recognition in modern societies of a fundamental right to insurance as a social good. ${ }^{59}$ On the other hand, to the extent that basic health and life insurance are deemed essential, it could be argued that they should be provided to everyone at affordable prices which did not factor in one's individual risk profile, in which case it would seem more appropriate for it to be financed out of taxation, rather than by having low-risk individuals subsidize high-risk individuals within the private insurance sector. ${ }^{60}$ In any case, it would be reasonable to say that society as a whole has an interest in the preservation of the private insurance market. This being so, the proportionality test should be called upon to if we are to balance both sets of interests. ${ }^{61}$

In this article I have looked only at insurers' use of sex as an actuarial factor, but I do believe that the adoption of the twofold test, as set out above, might be of use in the context of other suspect classifications, such as age. This is not the place to develop this idea. However, it should be noted that every suspect classification bears its own history, some, such as race, being more tainted by past discrimination than others. Our collective

\footnotetext{
${ }^{59}$ See L. WORTHAM, op. cit. supra n. 7; and J. GAULDING, op. cit. supra n. 7, at pp. 1688-1694.

${ }^{60}$ This argument was put forward by R. DwORKIN, Sovereign virtue. The theory and practice of equality, Cambridge University Press, 2000, pp. 435-436. The author added that private insurers should be allowed to offer extra health and life insurance at market rates, and that in calculating such rates they should be allowed to discriminate on the basis of each candidate's genetic profile (that was the example under analysis, not one's sex or race).

${ }^{61}$ Y. ThierY and C. V. SCHOUbroeCK, op. cit. supra n. 39, p. 208.
} 
sensibilities towards each suspect classification are constantly evolving. Presently, we might safely say that age is still not as sensitive a topic as sex, just as sex is perhaps still not as sensitive a topic as race, although the distance between the two might be decreasing. On the other hand, if we were to ban the use of age as an actuarial factor, the burden on the insurance industry would be much greater than that posed by the relinquishing of sex as an actuarial factor. Therefore, I would not be surprised if the industry were to pass this test successfully and be allowed to use age as an actuarial factor, at least in personal insurance, the proportionality test being a key element of the second part of the twofold test.

\section{Conclusions}

When it comes to the use of statistical findings as justification of a differentiation based on one of the suspect classifications set forth in Article 21(1) of the Charter, that they be accurate is not all we should be asking for in order for the presumption of wrongness therein contained to be set aside.

By recognizing that insurers' decisions to differentiate on the ground of a person's sex, or of any other suspect classification, are based on scientifically proven risk assessment methods accurately applying probabilistic theory to statistical data, all we are saying is that they are rational. The application of a stricter test should follow in order for a differentiation based on a suspect classification to fall on the good side of the line between admissible criteria of differentiation and inadmissible forms of discrimination.

Statistical analysis, by using past data to predict the future, can be used as an instrument to perpetuate past injustices in a way that is incompatible with the promotion of equality. The use of accurate statistical findings is intolerable, whenever these findings are based on suspect classifications, if the statistical regularities that are found could be traced back to 
some form of past discrimination. More rigorously, given the presumption of wrongness, the use of these statistical findings should be banned unless there is evidence in support of the conclusion that these differences and regularities have an explanation that is unrelated to some form of past discrimination.

In addition, the use of a suspect classification as an actuarial factor should also be deemed intolerable unless there is evidence in support of the conclusion that such factor plays a determining role in the relevant chain of events, or that the correlation which has been identified is particularly strong or meaningful in that it relies on the significance of a person's individual characteristics rather than on that person's membership of a historically discriminated social group. In sum, something stronger than mere convenience must have determined the choice of that suspect classification as an actuarial factor, to the detriment of other potentially relevant factors.

I put forward the proposition that a twofold test aimed at narrowing the rules allowing insurers to differentiate on the basis of a suspect classification should be used so as to separate admissible criteria of differentiation from inadmissible forms of discrimination. This test consists of the following two questions: 1 . Is there evidence in support of the conclusion that the statistical findings under consideration have an explanation that is unrelated to some form of past discrimination? This question should be answered affirmatively in order for the differentiation to pass this part of the test. 2. Comparing the actuarial factor under scrutiny with every other possible factor, is there evidence to support the conclusion that that there is no other known factor which (i) would have been more suitable as a predictor of the relevant outcome or (ii) which would have been equally or even slightly less suitable for that purpose from an actuarial perspective but which would 
have been less burdensome from a human rights perspective? This question should also be answered affirmatively in order for the differentiation to pass this part of the test.

The actuarial factor under scrutiny by the ECJ in Test-Achats was a person's sex. No argument is made in this article against the decision itself. However, if we leave sex discrimination aside and think about age as a factor in risk assessment, I believe it would not be too daring to expect that in some instances its use might pass this test. By omitting any reference to the possible rebuttal of the presumption of wrongness, thereby failing to explain the reasons why sex should not be used as an actuarial factor in the insurance business, the ECJ may have fuelled the conviction that the same treatment should be given to every other suspect classification in Article 21(1) of the Charter. That would certainly be the end of personal insurance as we know it. Hence, it would appear that the Court might have respectfully gone too far by saying too little. ${ }^{62}$ In the field of personal insurance, justice would be better served if it did not throw out the baby with the bathwater.

62 The terseness of the reasoning in the judgment was criticized by K. KOLDINSKÁ, "Case law of the European Court of Justice on sex discrimination 2006-2011”, (2011) 48 CML Rev., 1599-1638, at 1632-1637. E. NANOPOULOS, "Insuring the Charter: who bears the cost?", (2011) 70 Cambridge Law Journal, 506-508, notes that the Court did not consider that issue at all, merely pointing to a deficiency in Art. 5(2) of the EU Gender Directive, which, through its indefiniteness, frustrated the Directive's objective of combating discrimination under Article 19 TFEU and breached Arts. 21 and 23 of the Charter. 